\title{
Research Paper \\ The Effectiveness of Sensory Motor Integration on Gross Motor Skills of Students with Intellectual Disability
}

\section{Ali Akbari Sargari ${ }^{1}$, Somayeh Sadat Sadati Firoozabadi ${ }^{* 2}$}

1. M.A. in Psychology and Education of Exceptional Children, Faculty of Education \& Psychology, Shiraz University, Shiraz, Iran 2. Assistant Professor, Department of Psychology and Education of Exceptional Children, Faculty of Education \& Psychology, Shiraz University, Iran

Citation: Akbari Sargari A, Sadati Firoozabadi SS. The effectiveness of sensory motor integration on gross motor skills of students with intellectual disability. Quarterly Journal of Child Mental Health. 2020; 6(4): 241-252.

\section{http://dx.doi.org/10.29252/jcmh.6.4.22}

\section{A R T I C L E I N F O}

\section{Keywords:}

Gross motor skills, motor sensory integrity, educable mentally retarded students

\section{A B S T R A C T}

Background and Purpose: Motor skills are essential skills for learning and success in school. Movement and learning are the source of all perceptions and learning. In relation to motor impairments in students with intellectual disability, motor-sensory integration is one of interventions that is consistent with perceptual-motor theories. The purpose of this study was to investigate the effect of motor sensory integration exercises on the gross motor skills of students with intellectual disability.

Method: The present study was conducted with experimental design with pre-test, post-test, and follow-up period with control group. The study population consisted of all students with intellectual disability in Firoozabad city during the academic year of 2017-2018. The sample consisted of 30 students from this papulation (7-14 years old) who were selected by convenience sampling and then randomly assigned to experimental and control groups. The experimental group received motor sensory integration training for 10 sessions (two days a week), while the control group did not receive any training. In this study, the Bruininks-Oseretsky Test of Motor Proficiency, was used as pre-test, post-test, and follow-up for data collection. Multivariate analysis of variance was used to analyze the data.

Results: The results of the data analysis of this study showed that the intervention of motor sensory integration increased the scores of gross motor skills in the experimental group which remained stable after one month $(\mathrm{P}<0.001)$.

Conclusion: According to the findings of this study, it can be concluded that the intervention based on motor sensory integration method has been able to control basic motions, maintaining body posture or balance, lateral superiority, movement and orientation movements, body awareness and imagery, and thus improve motor skills in students with intellectual disabilities.
Received: 11 Mar 2018

Accepted: 30 Sep 2019

Available: 6 Mar 2020

\footnotetext{
* Corresponding author: Somayeh Sadat Sadati Firoozabadi, Assistant Professor, Department of Psychology and Education of Exceptional Children, Faculty of Education \& Psychology, Shiraz University, Iran.

E-mail addresses: Somayehsadati@shirazu.ac.ir
} 


\section{اثربخشى يكيارجكى حسى حر كتى بر مهارتهاى حر كتى درشت دانش آموزان كمتوان ذهنى}

\section{على اكبرى سر كرى'، سميه سادات ساداتى فيروز آبادى}

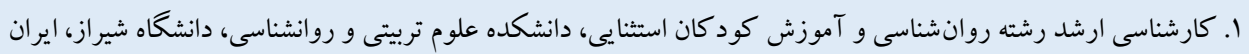

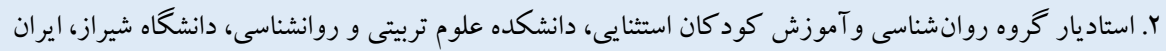

زمينه و هدف: مهارت هاى حر كتى از توانايىهاى اساسى براى ياديرى و موفقيت در مدرسه است. حر كت و ياد كيرى مبدأ تمام ادراكات

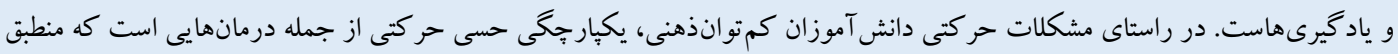

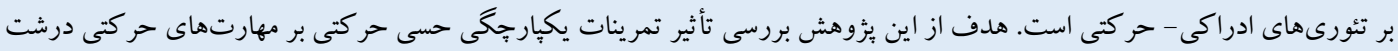

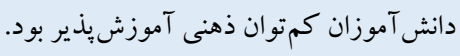

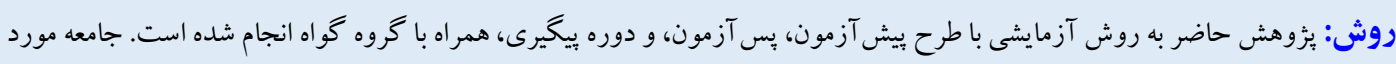

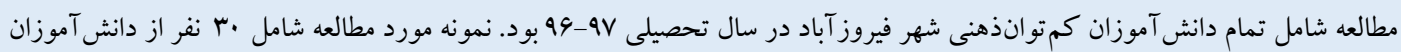

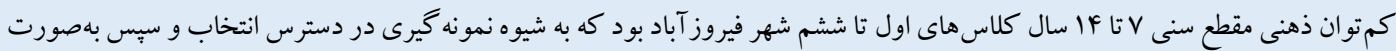

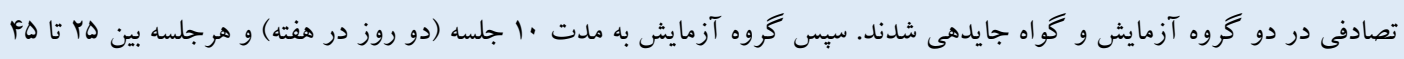

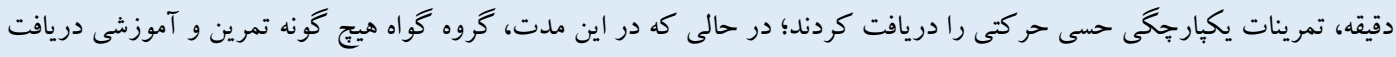

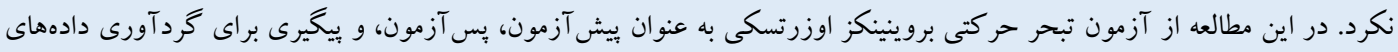

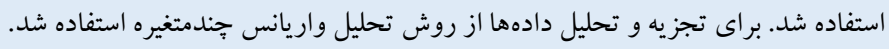

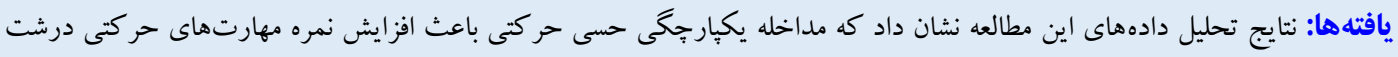

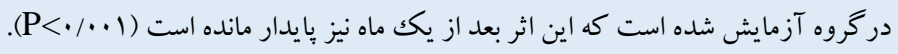

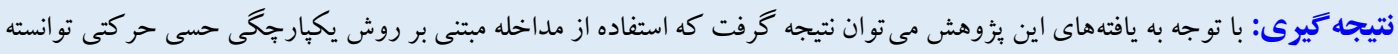

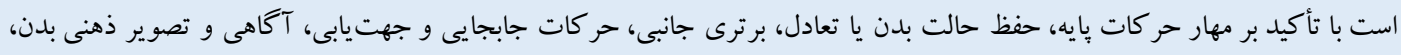


يكى از مهم ترين مشكلات دانش آموزان كم توانى ذهنى، اشكال در زمينه

مقدمه

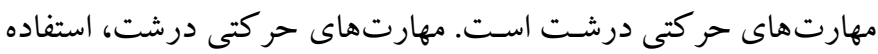
تاكنون تعاريف مختلفى از كود كان با كمتوانى ذهنى ' ارائه شده است

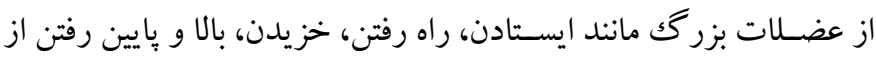

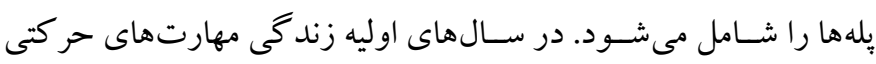
درشـت به گُنهاى تحول و توسعه مى يابند كه علاوه بر اكتشاف محيط، براى ثبات و مهار بدن نيز مورد نياز هستند (9). اين مهارتها بهصسورت

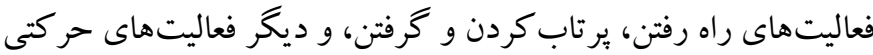

درشت و تعادل، گروهبندى شدهاند (V)

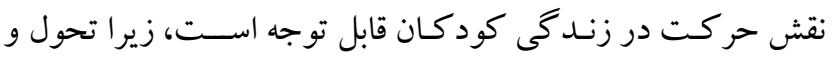

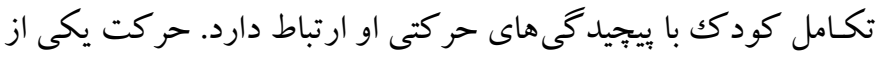
مهم ترين شـــوهــاى افزودن آكـاهى كود كـان اســت و در واقع اولين

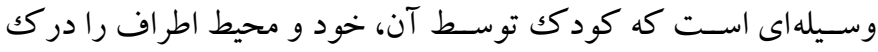

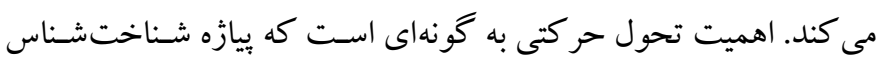
معروف و نظريسه يرداز در حوزه تحول شــناختى كود كان، بر اين اصـل

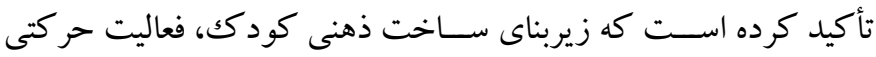

است كه در دو سال اول زندگى تحول مى يابد (^). مهارتهاى حر كتى يكى از مهارت هاى اساسى براى ورود به مدرسه

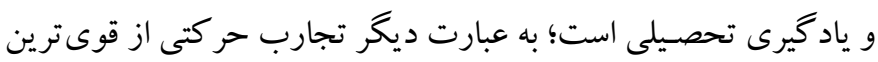

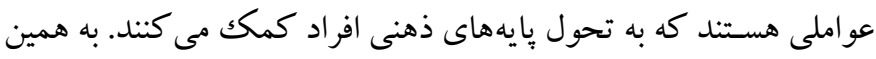

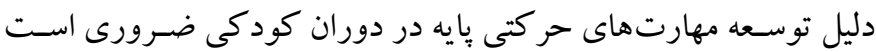
زيرا كود كان از طريق آنها، جهان بيرامون خود را كاوش مى كنند (9).

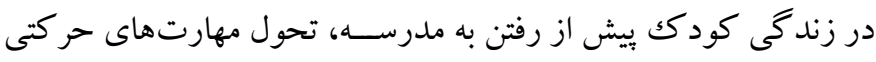

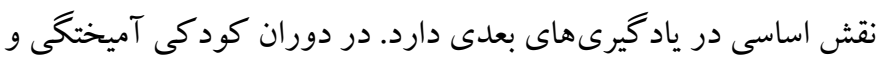

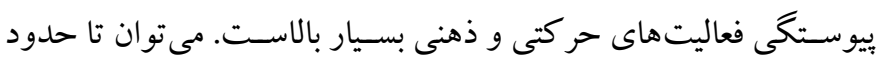

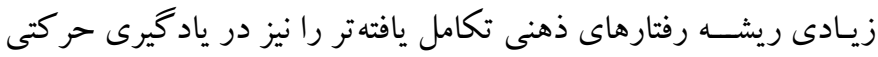

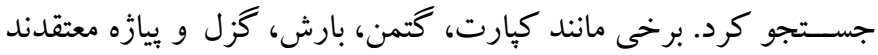

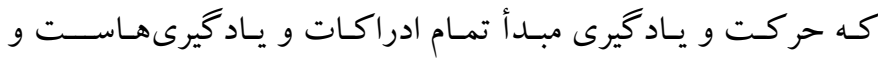

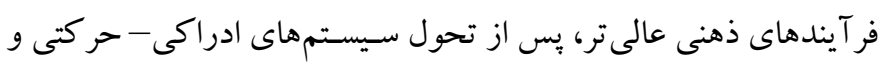

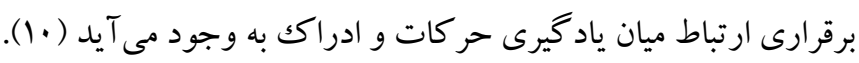

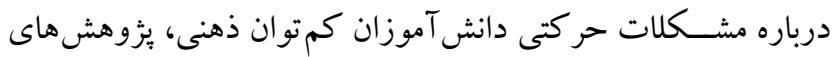

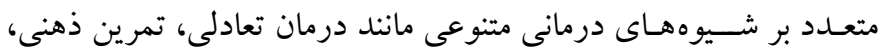
آمريكـا در آخرين ويرايش خود بـا ايجـاد تغييراتى نســبت به ويرايش قبلى، اين ناتوانى رادر زمره اختلال تحولى هوشى قرار داده و آن را بدين صسورت تعريف نموده اسـت: (ا كم توانى ذهنى (اختلال تحول هوشسى)، اختلالى اسـت كه در دوره تحول شـروع مىشود و در بر گيرنده نارسايى در كاركرد ســازشـى و هوشــى فرد در حوزههاى عملى، اجتماعى، و مفهومى است. انجمن روانيزشكى آمريكا در جديدترين تقسيمبندى خود با توجه به شـدت و بر اساس عملكرد سازشى، كمتوانى ذهنى را به جهار دسته خفيف، متوسـ، شديد و عميق تقسيم كرده است ( (1). ميز ان بروز كم توانى ذهنى بـا توجـه بـه تعـاريف مختلف از اين اختلال و هميجنين با توجه به نحوهُ جمع آورى اطلاعات، متفاوت اســت. در جديدترين آمار، انجمن روانيزشـكى آمريكا شـيوع اين اختلال را در حدود يكك درصـد

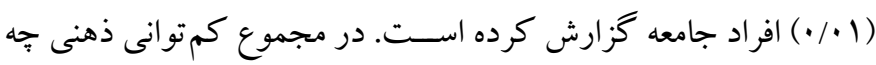
در انواع خفيف (نسبت مرد به زن 9/9 به 1) و جه در انواع شديد (نسبت ميانگين مرد به زن ب/ به () در مردان شايعتر است (Y).

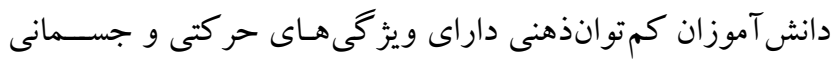
خاصى هستند. اين افراد به دليل محدوديت در كار كرد ذهنى و رفتارهاى سـازشى، داراى ويثز كى هاى تأخيرى حر كتى برجسته بوده و آسـيب در عملكرد حسى و حر كتى، روى سـيستمهاى عصبى و عضلانى اسكلتى و حسى حر كتى تأثير خواهد داشـت. وضعيت بدنى اغلب اين افراد بهطور معمول ضـعيف بوده و شـادابى جسـمى جندانى ندارند (r). در مطالعات مقايسـهاى حيطه حر كت، نشـان داده شــده اسـت كه افراد كم توان ذهنى نســــت بـه افراد بهنجـار در زمينـه قدرت بدنى، تحمل، جابكى، تعادل، ســرعـت دويـدن، همـاهنكى حر كتى، انعطـاف يذيرى، و زمان واكنش، امتيازهاى كمترى به دست مى آورند. اين دانش آموزان نسبت به همسالان بهنجار خود Y تا F سال تأخير حر كتى نشان مىدهند (F). علاوه بر اين در زمينهُ مهارتهاى زبانى، نوشـتارى، تو انايىهاى تحصـيلى مانند خواندن، ريـاضــــات و قـدرت ادراكى، ظرفيـت حـافظه، خلاقيت و مهارتهاى حر كتى نسبت به همسالان خود از توانايى يايينترى برخوردار هستند (ه). 
احتمالًا مى تواند منجر به ايجاد يك بِاسـخ تطابقى در مغز شـده و كارايى

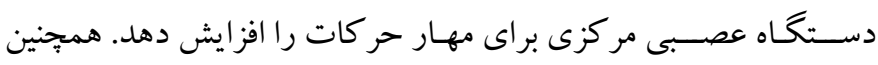

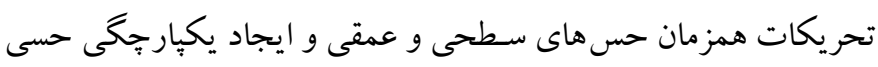

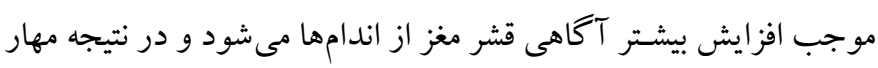

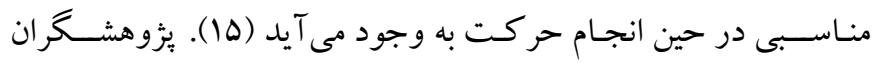

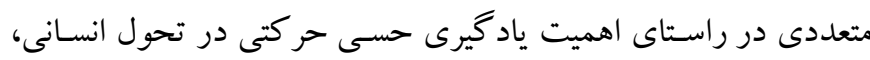

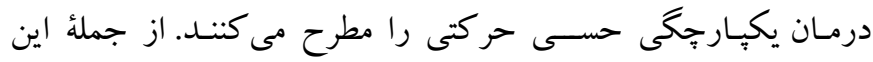
مطالعات مىتوان به بُزوهش فارسسى، عبدلى، كاويانى و كاويانى (19)

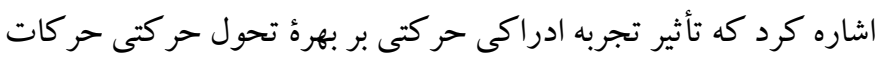

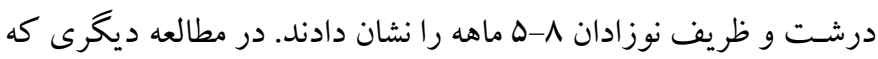

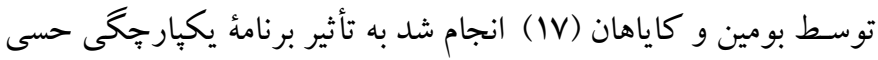

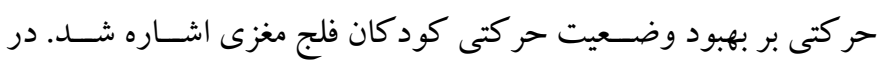

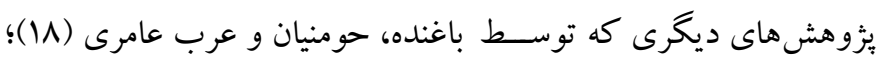

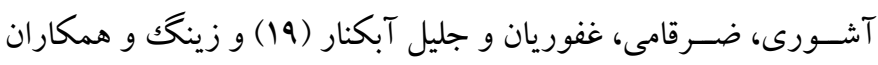

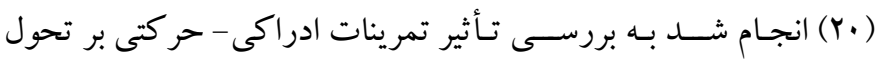
مهارتهاى شـناختى و حر كتى كود كان كم توان ذهنى برداختند و نشـان

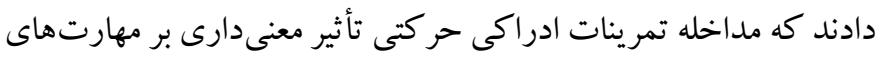

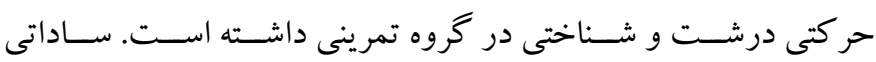

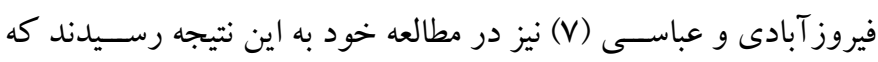

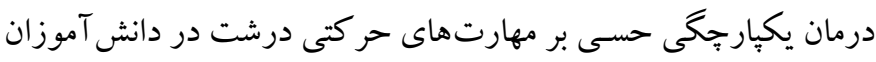

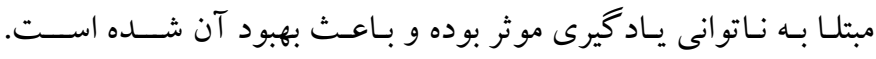

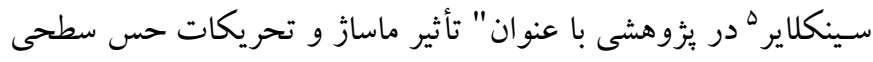

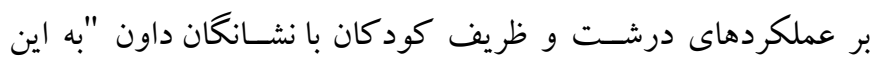

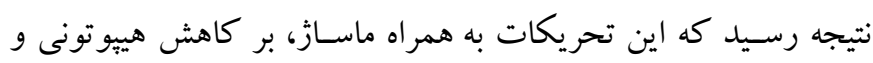

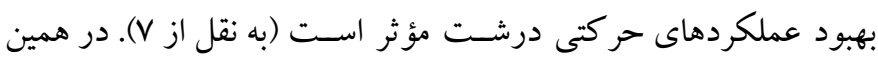

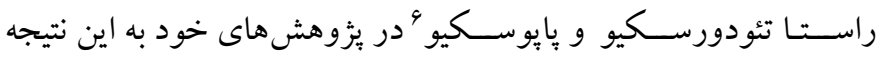
رسيدند كه سـيستم هاى اصلى حر كتى يعنى سيستم وستيبولار و سيستم

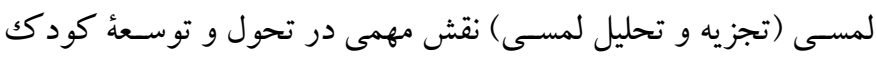

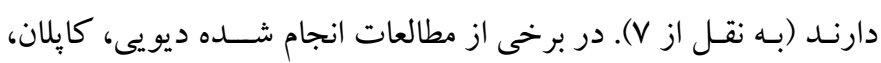

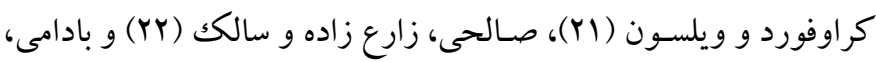

\section{Vestibular}

5. Sinclair

6. Teodoreskeu \& Papoeskeu

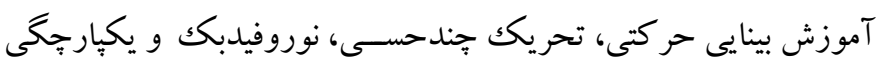
حسى حر كتى' براى مشكلات اين دانش آموزان تمركز كردهاند. از جمله

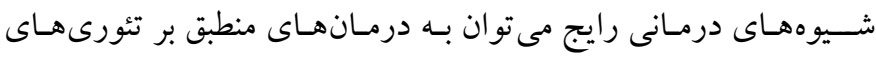

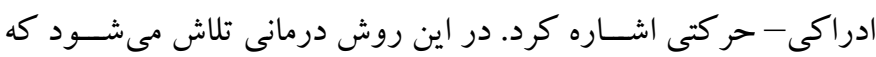

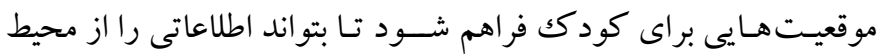

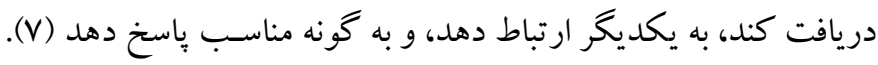

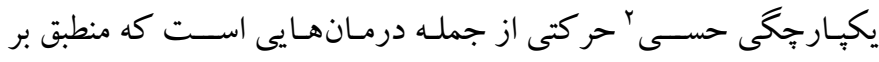

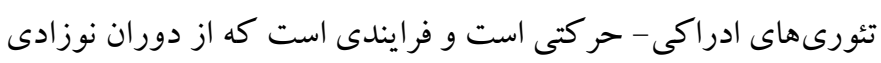

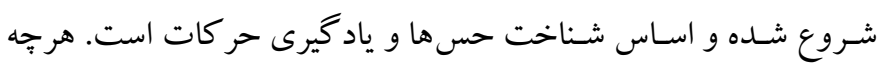

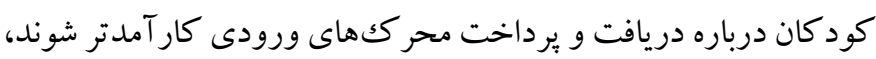

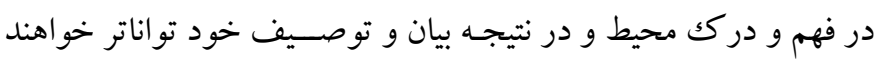

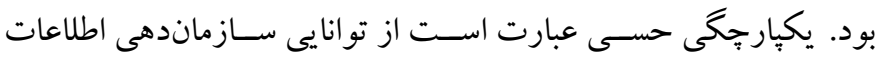

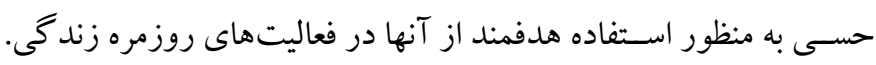

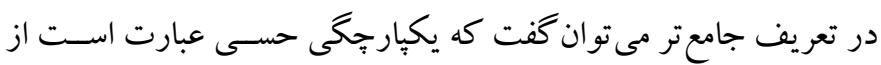

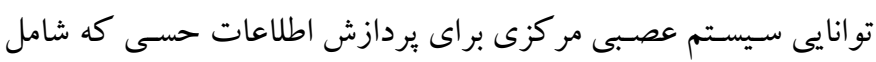

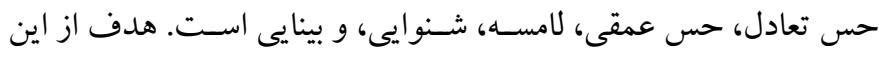

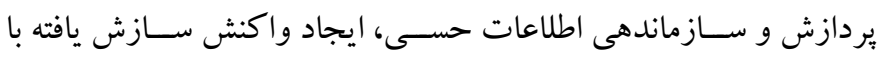
محيط است ( •) (1).

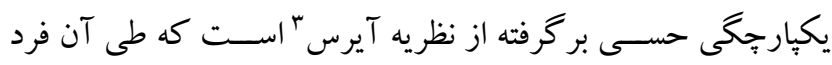

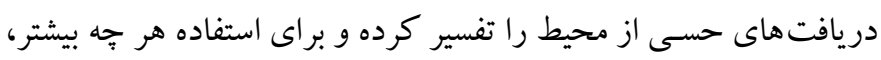

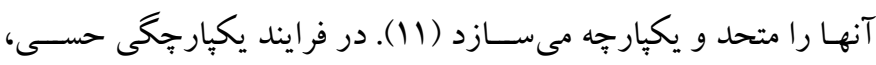
تمر كز عمده روى سـه حس لامسـه، وستيبولار ( (تعادلى)، و عمقى است.

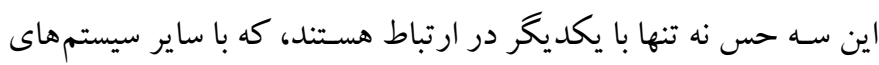

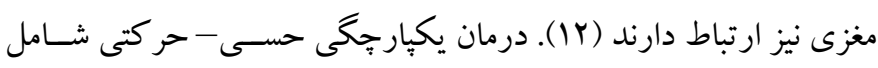
تحريكات حسى مهار شدهاى است كه بهصورت فعاليتهاى خودفرمان

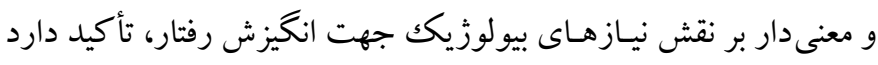

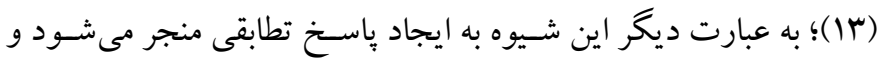

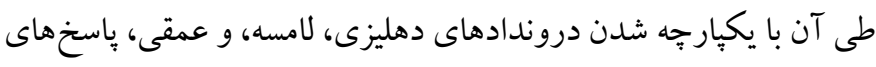

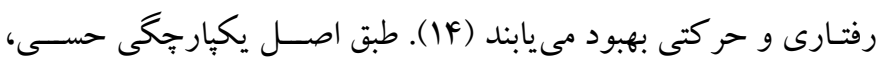

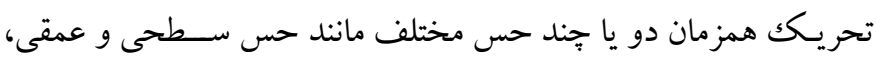

1. Motor sensory integrity

2. Motor sensory integrity

3. Aires 


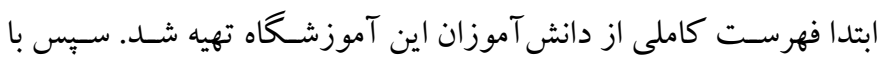

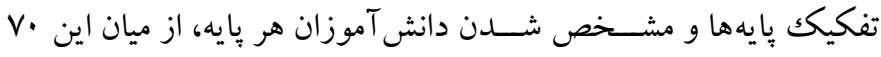

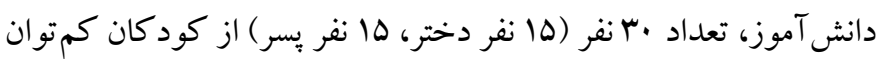
ذهنى اين مركز كه با توجه به نظر تخصـصسى مربى تربيت بدنى و معلم

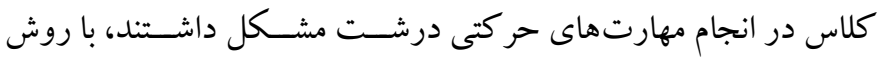

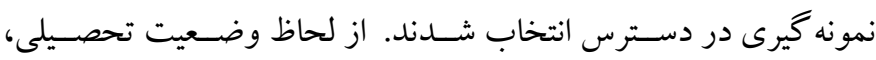
اعضـاى نمونه از بين كلاس هاى يكم تا شـشــم كم توان ذهنى كه قادر به

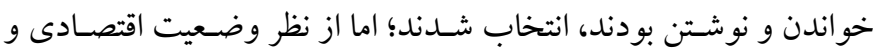

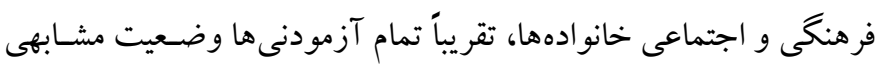

ا. آزمون تبحر حركتى بروينيكز اوزرتسكى': بروينينكز در سال I9VY

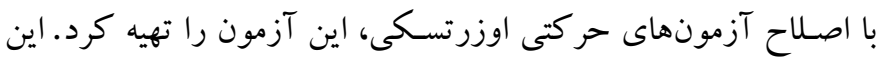

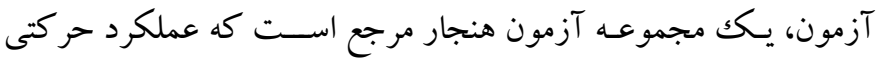

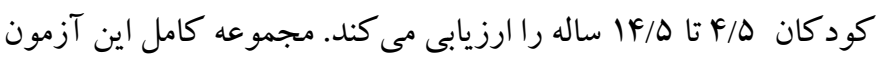

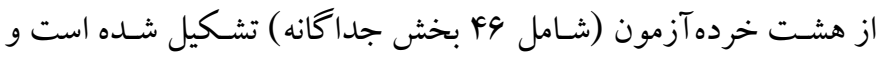

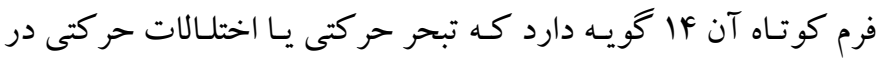
مهارتهاى حركتى درشت و ظريف را ارزيابى مى كند. اجر اي مجموعئ

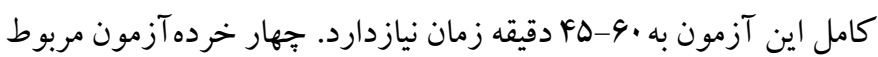

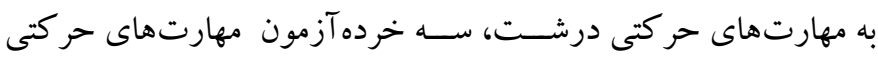
ظريف، و يكك خردهآزمون هر دو مهارت حر كتى را ارزيابى مى كند. با دها

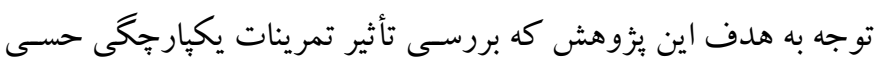

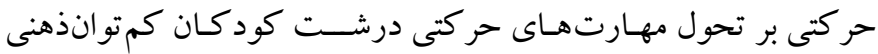

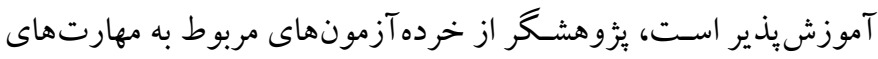

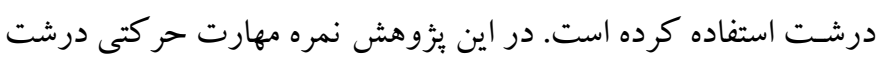

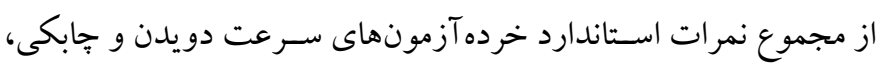

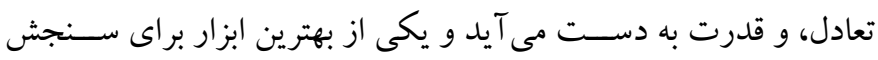

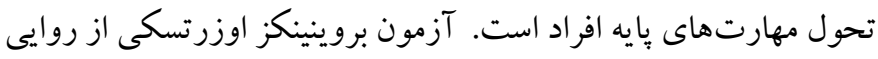

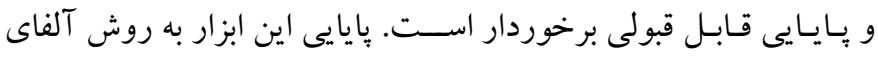

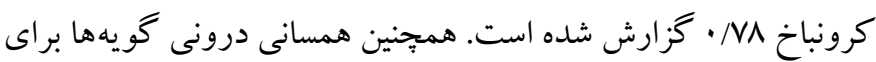

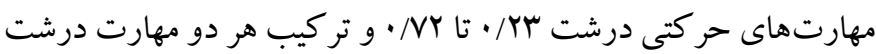

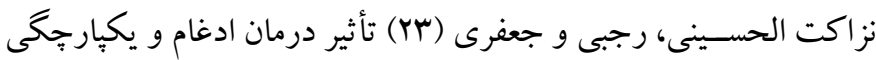
حسـى حر كتى بر مهارتهـاى حركتى و تعـادل در كودكـان با اختلال

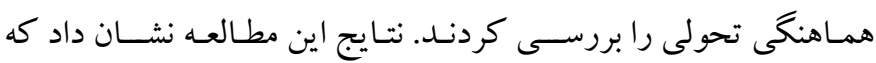

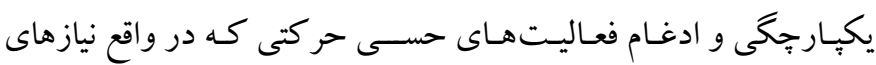

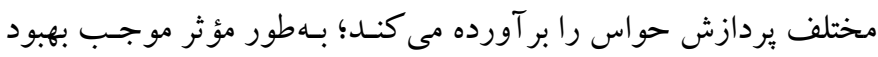

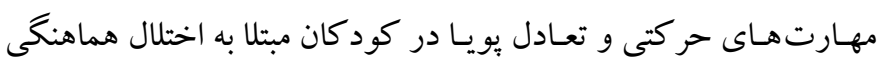

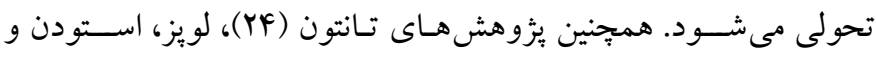

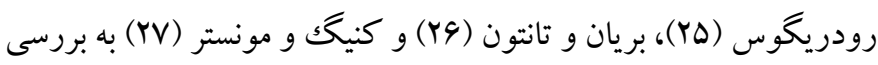

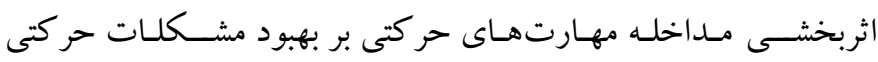

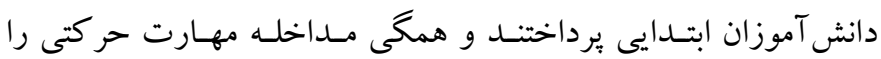
معنادار و اثربخش گز ارش كردهاند.

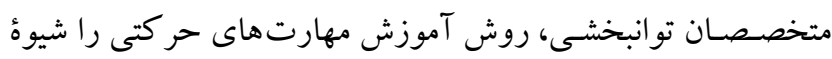

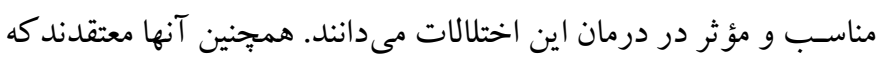

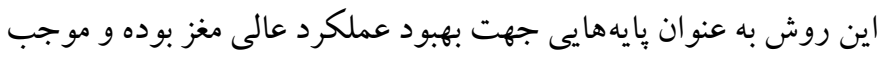

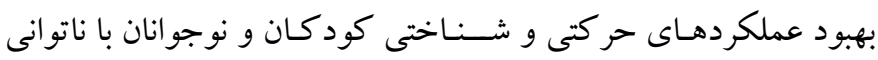

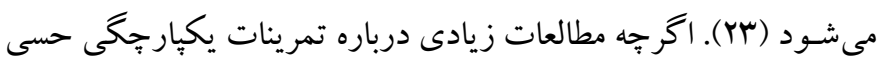

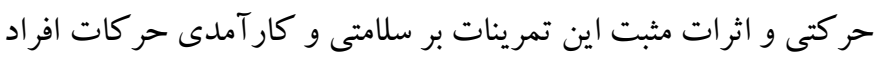

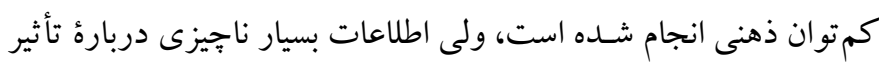

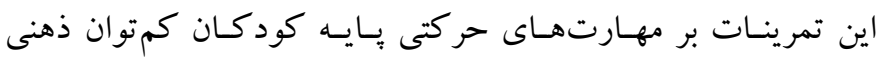

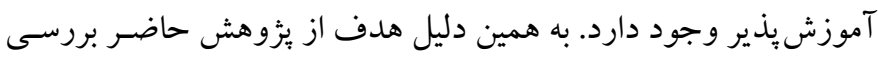

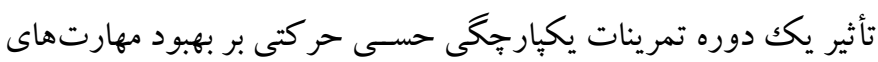
حر كتى درشت دانش آموزان كمتوان ذهنى آموزش يذير است.

روش الف) طرح يزوهش و شـر كت كنند كان: روش اجر ایى اين يزوهش

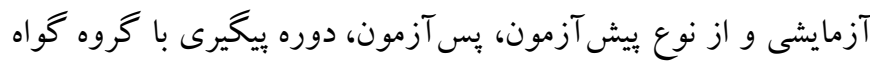

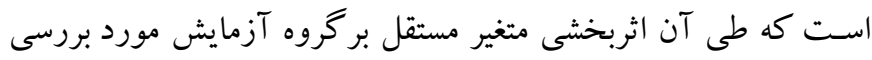

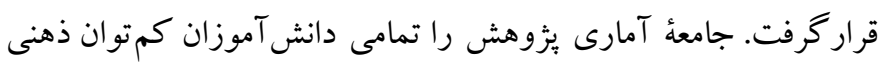

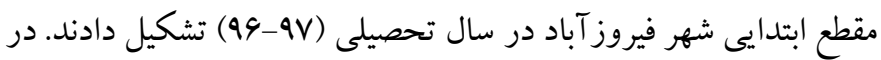

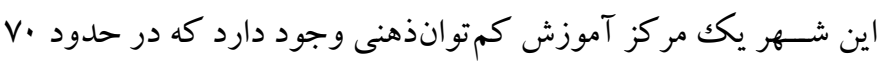
دانش آموز كم توان ذهنى را تحت بوشش قرار مى دهد. براى نمونه گيرى 


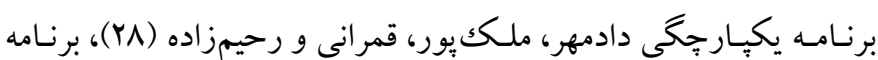

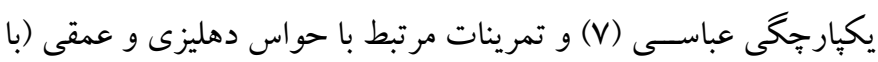
تأكيد بر حواس دهليزى و عمقى) بر گرفته از برنامه فعاليت هاى مربوط به يكֶ) شده است. اين برنامه داراى تمرين هايى است كه براى موفق شدن در آن

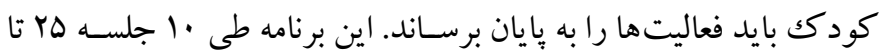
ها دقيقـهاى (دو روز در هفتـه) توســط يززوهشــكر در حياط و يكى از سـالنهاى مدرسـه بر روى گرووه آزمايش انجام شد. در جدول ا خلاصه

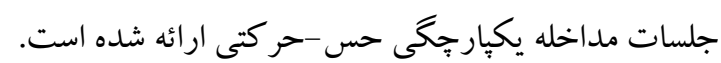

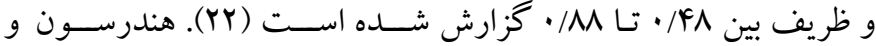
سـاكدون' روايى همزمان بين نمره كل آزمون ارزيابى حركت كود كان و آزمون بروينينكز اوزرتسـى رابراى سو كودك F تا r ا ساله سه/ • به دســت آوردنـد. كروس، هوروات و مكك كارتى ب روايى همزمان آزمون ارزيـابى حركت كودكـان و شــكـل بلنــ و كو تـاه آزمون بروينينكز اوزرتسـكى را با نمونهاى به تعداد 9.ا بِسر و دختر ه تا با ساله ارزيابى كردند كه روايى آن بر اسـاس ضريب همبستكى بيرسون بين 19 • تا 9 / . كزارش شد (به نقل از سr). ج) برنامه مداخلهاى: درمان يكֶيارجّى حسـى حركتى در اين مطالعه منطبق بر تئورىهاى ادراكى - حركتى بوده است كه نوع تمرينات آن از

\section{جدول 1: خلاصه جلسات مداخله يكيارجگى حسى - حر كتى}

\begin{tabular}{|c|c|c|}
\hline فعاليت انجام شده و نحوه انجام & هدف & شماره جلسه \\
\hline هر يكك از دانش آموزان روى خط جين هاى مشخص با استفاده از يكك طناب براى سه مر تبه و هر بار به مدت بيست & تقويت عضلات ياها & جلسه يكم \\
\hline كاغذهايى به دانش آموزان داده شد تا با مجاله كردن آنها توب هاى كاغذى درست كرده و به سمت هدف معينى & تقويت عضلات انگشتان و تقويت بازوها و عضلات & جلسه دوم \\
\hline 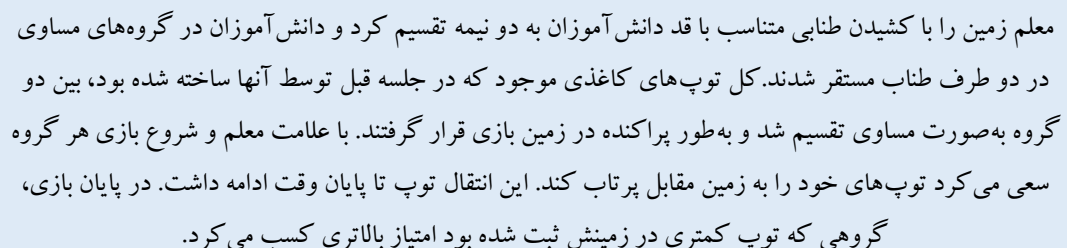 & تقويت مهارتهاى عضلات شانه و بازوها درشت & جلسه سوم \\
\hline 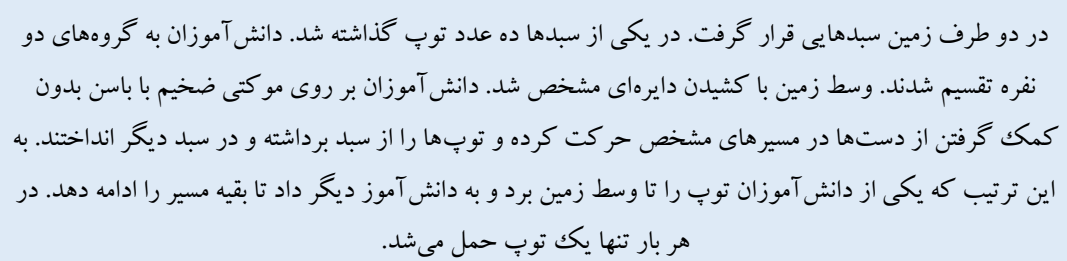 & تقويت عضلات دست و يا، & جلسه جهارم \\
\hline 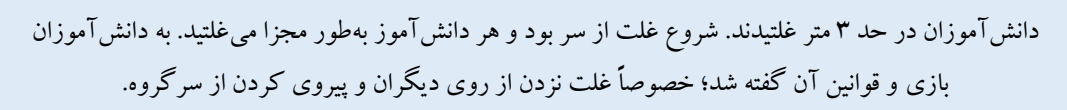 & تقويت عضلات سر و گردن، مهارتهاى حر كتى & جلسه ينجم \\
\hline دانش آموزان به گروههاى دونفره تقسيم شدند هر دانش آموز به كمك همكروهى متر باش بادست هاى خود به ميزان 9 & تقويت عضلات دست و يا و كمر و شانه و گردن. & جلسه ششم \\
\hline تكرار جلسات اول و دوم & & جلسه هفتم \\
\hline تكرار جلسات سوم و جهارم & & جلسه هشتم \\
\hline تكرار جلسه ينجم & & جلسه نهم \\
\hline تكرار جلسه ششم & & جلسه دهم \\
\hline
\end{tabular}


در هر مرحلـهاى از انجـام مــداخله از ادامه همكارى امتناع كنند؛ بنابراين اين مطالعه با رضـايت كامل دانش آموزان و والدين آنها انجام شــد. در يايان براى تحليل دادهاى از تحليل كوواريانس استفاده شد.

\section{افافته}

جدول زير ميانگين يِش آزمون، يس آزمون، و يِيخيرى نمرههاى دو كروه را در مهارت هاى حركتى درشت نشان مىدهد.
د) روش اجر ا: بعـد از كســـب مجوزهــاى علمى و ادارى از مراكز و مؤسسه هاى ذيربط، ابتدا با دعوت از والدين طى جلسهاى هدف از انجام اين يثزوهش براى آنـان تبيين شــد و از محر مـانـه بودن اطلـاعات به آنها اطمينان خاطر داده شد. بعد از آن اعضاى گروه نمونه به صورت تصادفى در دو گروه آزمـايش و گواه قرار گرفتند. ســـس دانش آموزان كروه آزمايش طى ·1 جلسه DY تا ها دقيقهاى (دو روز در هفته) تحت مداخله

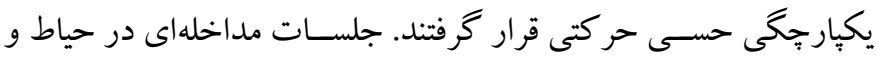
يكى از سالن هاى مدرسه به انجام رسيد.افراد نمونه اين حق را داشتند كه

\section{جدول r: ميانكين و انحر اف معيار كروههاى كواه و آزمايش در مهارتهاى حر كتى درشت}

\begin{tabular}{|c|c|c|c|c|c|c|}
\hline \multicolumn{6}{|c|}{ ميانتين (انحر اف معيار) } & \multirow{3}{*}{ متغير } \\
\hline \multicolumn{3}{|c|}{ آزمايش } & \multicolumn{3}{|c|}{ كواه } & \\
\hline يَيكيرى & يس پَآمون & يیش آزمون & بيَيرى & يس پَآزمون & يِيش آزمون & \\
\hline$M F / M T$ & $M F / M r$ & rr/FG & $r F / \Delta r$ & $r \Delta / .4$ & ro/Aq & \\
\hline$(৭ / \wedge \Delta)$ & $(1 \cdot / r \Delta)$ & $(1 \cdot / \mathrm{VA})$ & $(9 / 19)$ & $(\Lambda / \Delta \Lambda)$ & $(9 / 94)$ & يرشت \\
\hline
\end{tabular}

بـهـ منظور بررسـى معنـادارى تفـاوت دو زروه بـا توجـه به شــــايط بيش آزمون، يس آزمون، و بيخيرى از روش تحليـل واريـانس مختلط استفاده شد. براى بررسى بيشفرض نرماليتى اين روش آمارى از آزمون شـرط كرويت (موجلىى) اسـتفاده شـد كه نتايج نشـان داد مقدار آزمون كرويت مو جلى (MAF/• در سطح خطاى بزركتر از ه • • • معنى دار نيست ( • (19 •)؛ بنابراين مفروضسه اساسى تحليل واريانس مختلط مبنى بر برقرار بودن بيش فرض كرويت برقرار اسـت و مى توان به درستى از اين آزمون استفاده كرد كه نتايج آن در جدول سز ارش شده است.
همان طور كه در جدول r ملاحظه مىشود آزمودنىها در يس آزمون عملكرد بهترى نسـبت به ييش آزمون داشتهاند؛ بدين صورت كه ميانگين گروههاى گواه و آزمايش در بس آزمون افزايش يافته اســت. در مرحله بيكيرى ميانگين گرووهاى كواه و آزمايش تقريباً بدون تغيير بوده اســت

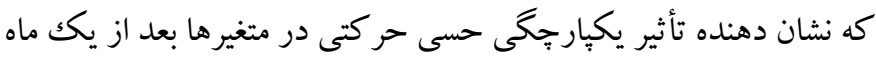
است. براى بررسى نرمال بودن دادهها از آزمون كالمو گروف-اسميرنوف استفاده شد كه مقادير سطح معنادارى بزر گتر از هـ • • به دست آمد، يس بـ مى توان كفـت كه اين متغيرها به لحاظ توزيع دادهها نرمال هســتند و در تحليل فرضــيه هاى يزٔوهش مى توان از آزمونهاى بار امتريكك اســتفاده

جدول با: تفاوت دو كروه در مهارتهاى حر كتى درشت در سه شرايط (بيش آزمون، يسآزمون، و يِيَيرى)

\begin{tabular}{|c|c|c|c|c|c|}
\hline سطح معنادارى & $\mathbf{F}$ & ميانكن مجذورات & درجه آزادى & مجموع مجذورات & منبع تغييرات \\
\hline$\cdot / \cdot \wedge F$ & $r / \Delta \Delta Q$ & $994 / 4 F$ & 1 & $994 / F F$ & اثر گروه \\
\hline$\cdot / \cdots *$ & rV/GMF & $Y F \cdot / 9 T$ & r & FAI/KG & اثر تكرار \\
\hline \multirow[t]{2}{*}{$\cdot / \cdots *{ }_{*}$} & $F \cdot / Q F \Delta$ & $r \Delta G / \Delta F$ & r & $\mathrm{V} \mid \mathrm{r} / \cdot \mathrm{A}$ & اثر تعامل \\
\hline & & $\Lambda / v \cdot \Lambda$ & $\Delta 9$ & FAV/GA & خطا \\
\hline
\end{tabular}

بنابر اين در اين مورد بايد كفت كه بين ميانگين مهارت حر كتى درشــت در گروه گواه و آزمـايش در مرحله بيش آزمون، يس آزمون، و مرحلـه
همـان طور كه جدول ب نشــان مى مهد اثر تعاملى كروه و آزمون با

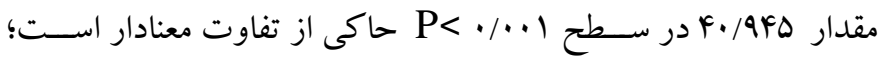


در كـدام آزمونها با ميانخين ديخر گروه، تفاوت وجود دارد از ميانخين

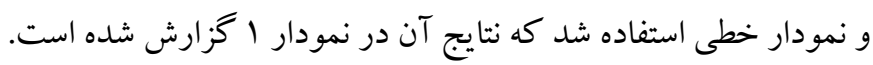

ييكيرى تفـاوت وجود دارد. در نتيجه تعـامل شـــايط (تكرار) در گروه

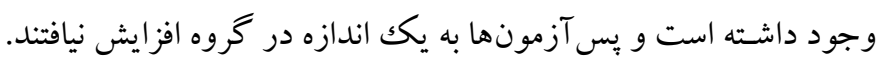

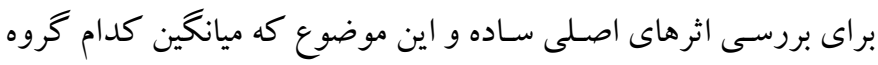

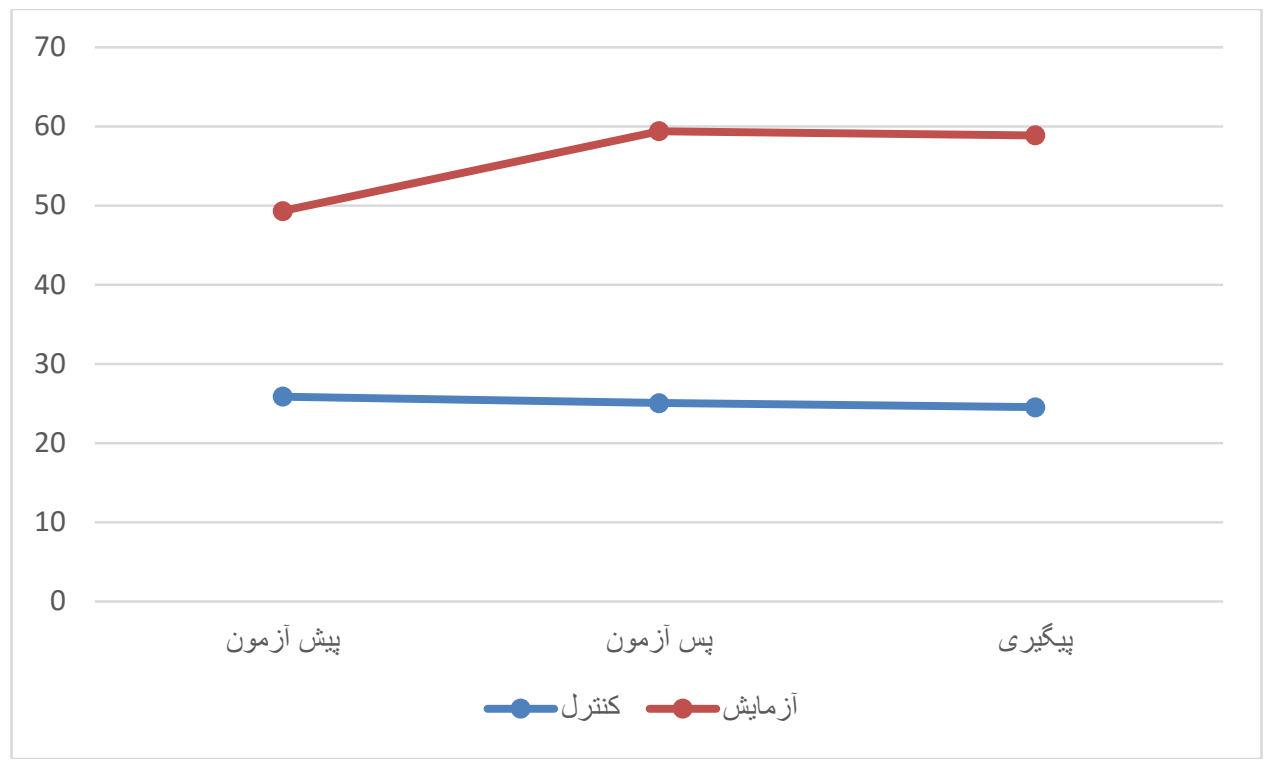

نمودار 1: نمودار تعامل اثر تكرار و كروه

نتيجه گيرى مى شود كه تمرينات يكيارجگى حسى حر كتى موجب بهبود

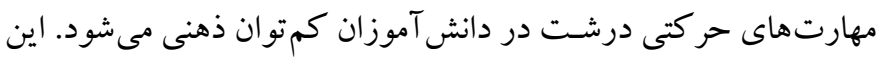

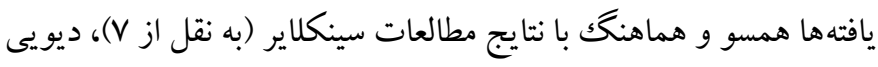

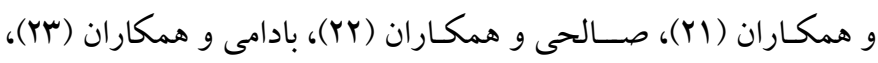

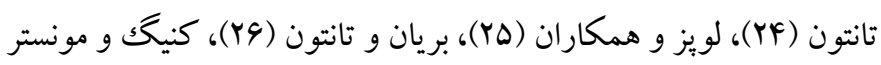
و و دادمهر و همكاران (YN) همسو است كه همه اين يُزوهش ها نشان دادند كه تحريك حس و حركت در بهبود عملكرد حر كتى مؤثر است.

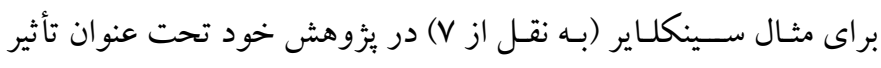

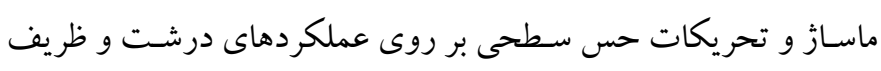

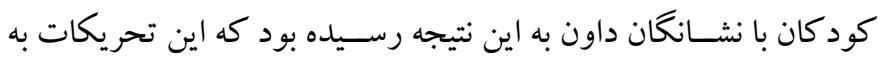

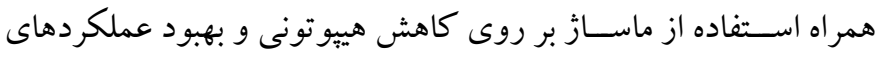
درشـت و ظريف مؤثر اسـت. در بزوهشى ديخر ديويى و همكاران (YI)

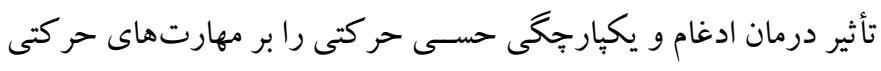

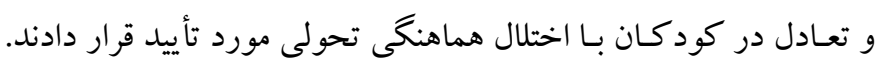

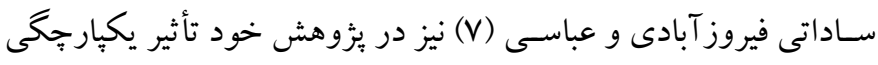

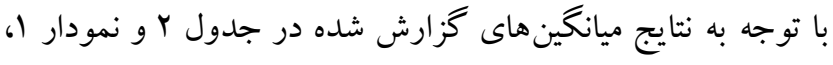

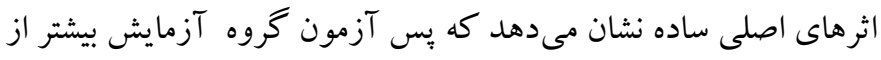

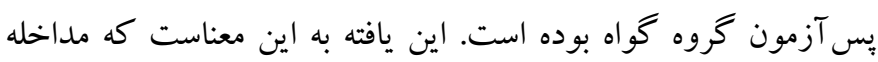

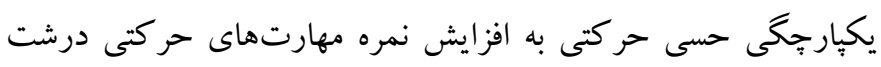
درگروه آزمايش منجر شده است و در نتيجه باعث بهبود مهارتهاى بهري حر كتى درشت شده است.

\section{بحث و نتيجه كيرى}

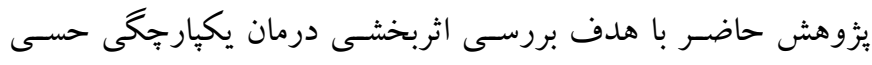

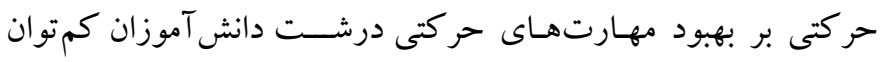

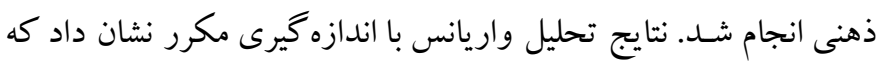

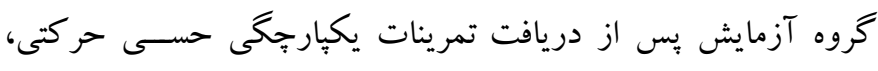

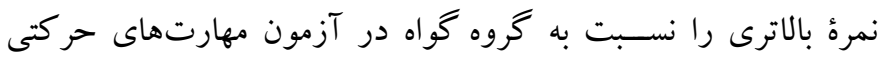

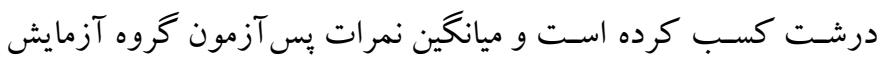

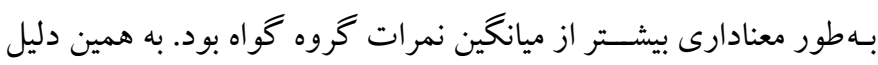


حالت بدن يا تعادل، برترى جانبى، حركات جابجايى و جهتيابى،

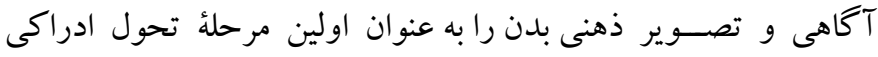

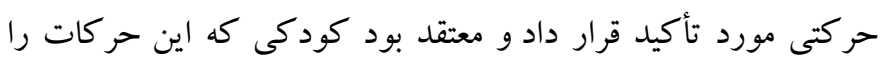

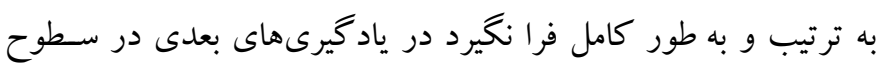

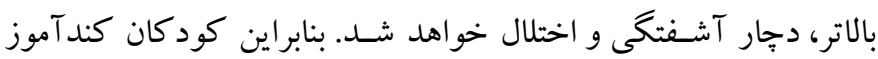
كه از نظر تحول عقب افتادهاند، كسانى هستند كه اين مراحل تحول را را در جهارجوب معين زمانى طى نكردهاند. به عقيده كيارت ممكن است

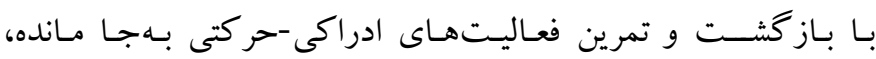
مهارتهاى اين كود كان اصلاح و ترميم بذيرد (V). نتـايج اين مطالعه به نوعى با نظريه تحول حر كتى هب نيز مطابقت و همخوانى دارد. وازههايى كه در ارتباط با اين نظريه مطرح مىشـــند

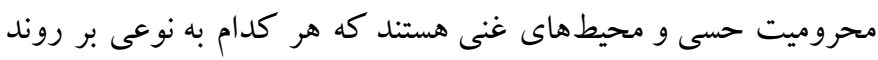

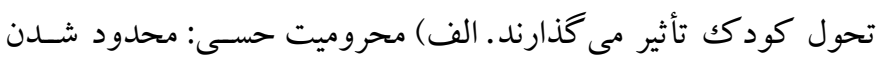

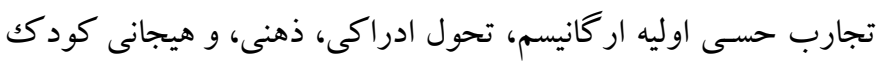

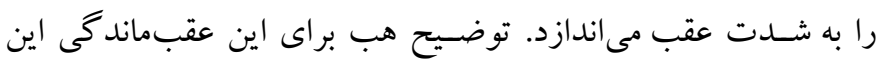

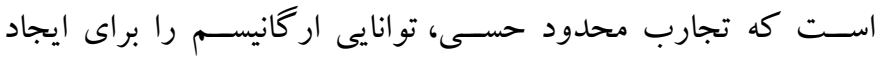

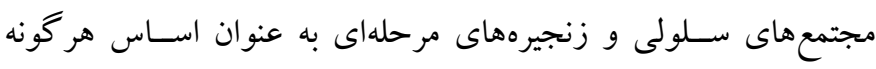

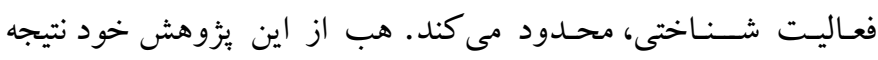

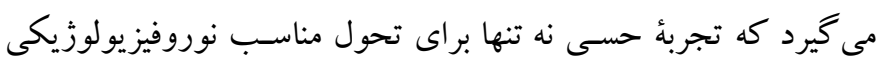
ضرورى است، كه براى حفظ كاركرد طبيعى نيز للام است. ب) محيط

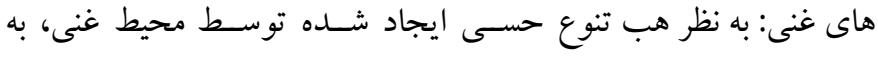

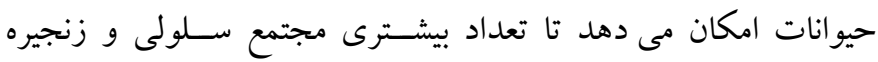

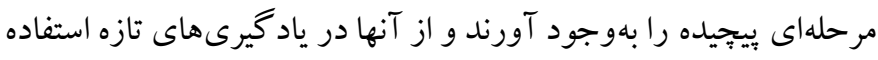
كنند. سؤال مهمى كه در اينجا مطرح مى شــود اين اسـت كه آيا آثار

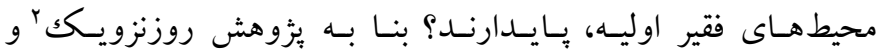

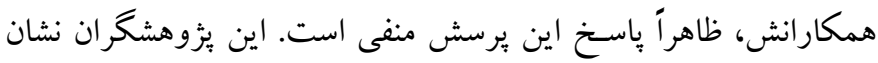

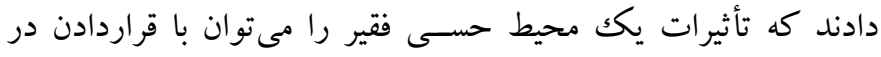

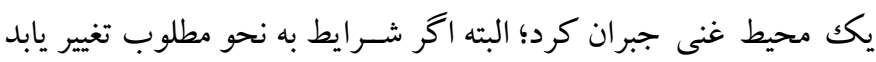

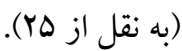

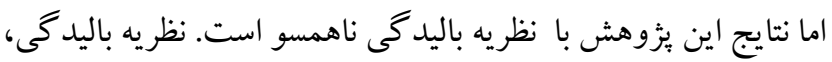

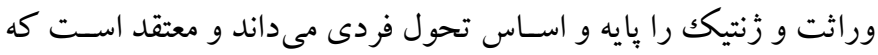

2. Rosenzweick
حسى حر كتى بر بهبود مهارتهاى حر كتى درشت دانش آموزان مبتلا به

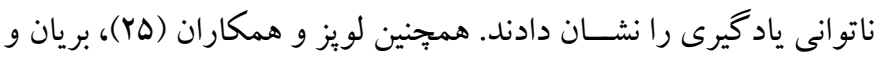

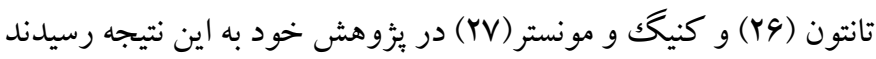
كـه برنـامههاى مداخلهاى مبنى بر مهارتهاى حر كتى مى تواند بر بهبود مشكلات حر كتى دانش آموزان اثربخش باشد. ماند.

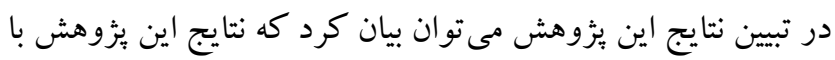

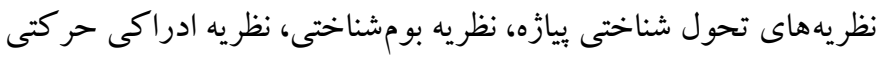

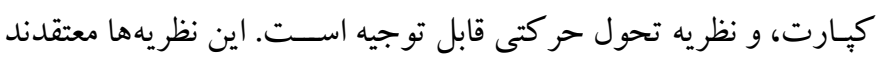

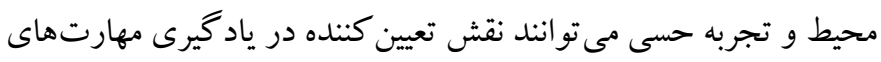

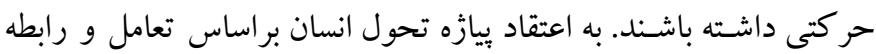
متقابل بين فرد و محيط است و انسان با طى مراحل تحولى در اثر ايجاد

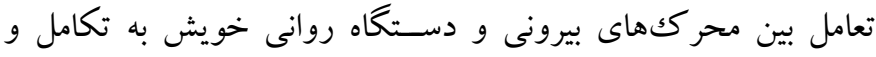

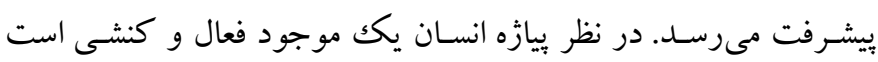
كه با محيط ييرامون خود ارتباط برقرار كرده و آن را ساماندهى و مهار

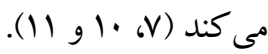

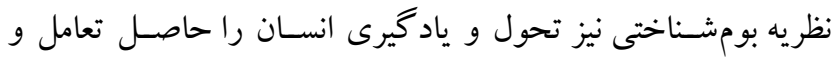
ارتباط متقابل بين فرد، محيط، و تكليف مىداندو هر ســه عامل رادر تحول حر كتى مؤثر مى دانـد. اين نظريه (بر خلاف نظريه باليدگى كه تهن تنها

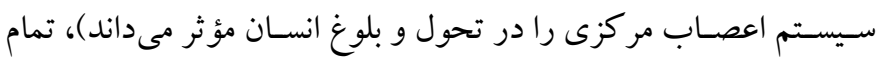
دستخاهها و سـيسـتمهاى بدن را در تحول انسـان دخيل مىداند. نظريه

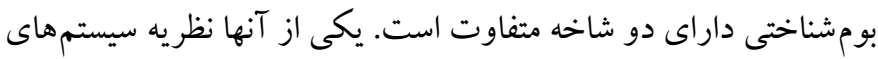

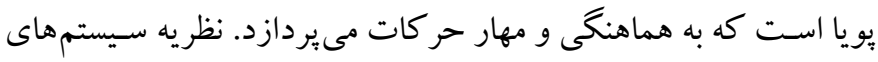

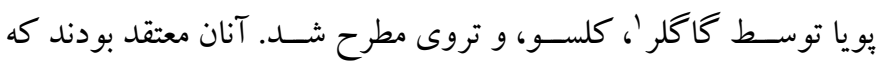

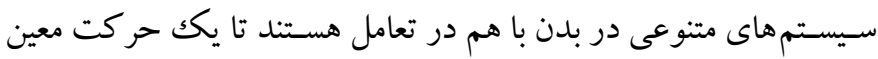

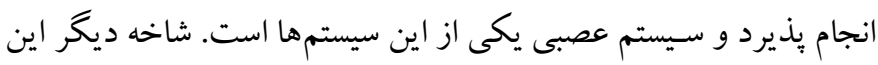
نظريه، ادراكى كنشى است كه بر اساس آن، بين سيستم ادراكى و سيستم حر كتى بدن، ارتباط مستقيم وجود دارد (11).

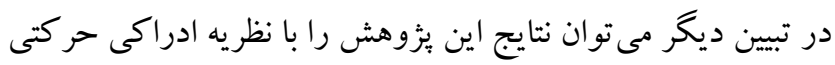

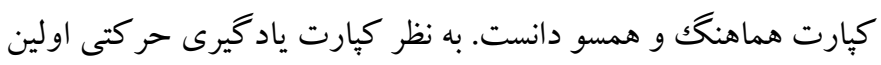

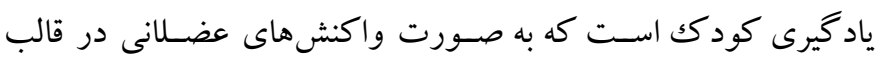
الكوهاى حركتى معين ظهور مى يابد. كيارت مهار حركات بايه، حفظ

1. Gagler 
سـاير كود كان با نيازهاى ويزه، همخن سـازى نمونه ها بر اسـاس وضسعيت

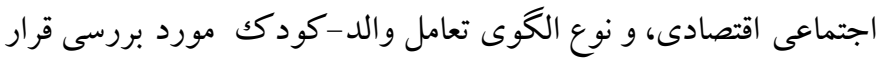

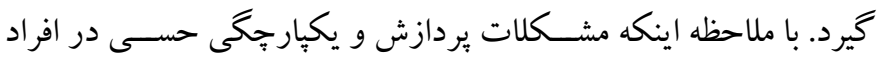

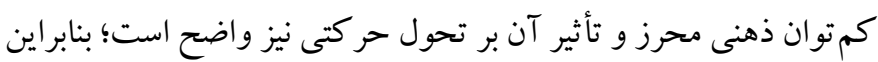

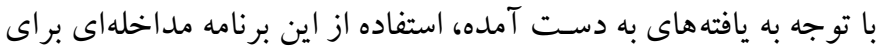

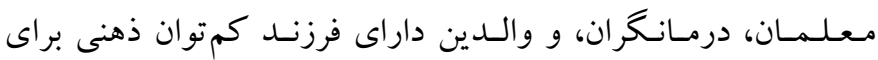
برنامهريزى هاى درمانى دقيق و مفيدتر، بيشنهاد مى وشود.

تقدير و تشـكر: اين بثوهش بر كرفته از بايان نامه كارشـاسـ ارشــ در رشته

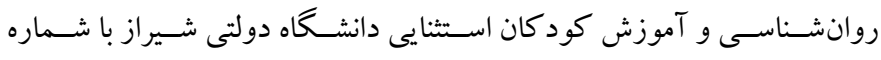

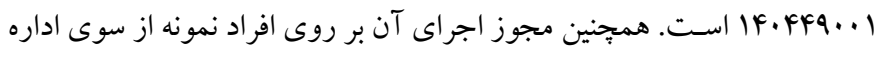

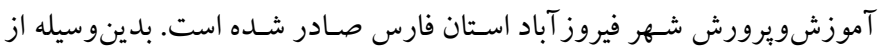

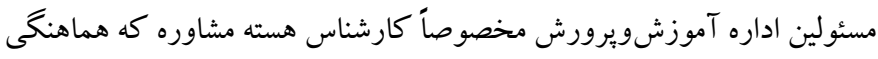
لـازم بـا مـدارس جهـت آموزش و يثزوهش را انجـام دادنـد و همجينين از مـدير محترم مر كز آموزشسى جناب رضـا فيروز آبادى، كادر ادارى و مربيان مدارس،

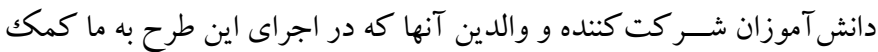

$$
\text { كردند، تشكر و قدردانى مى شود. }
$$

تضـاد منافع: انجام اين يثزوهش براى نويسند كان هيج گونه تضاد منافع نداشته است.
تحول هر فرد براســاس عوامل ارثى و نوعى تعيين مىشــود و ســــــمتم

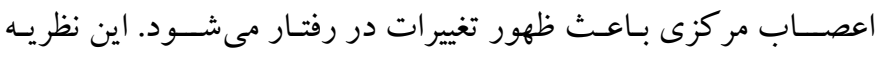

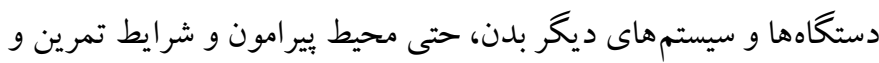

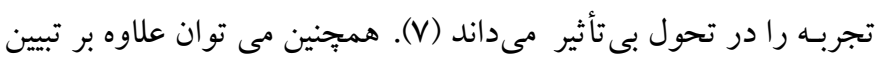

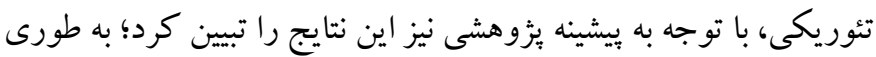

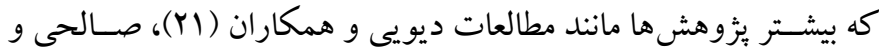
همكاران (YY)، بـادامى و همكـاران (YY)، تانتون (YY) (YY)، لويز و همكاران

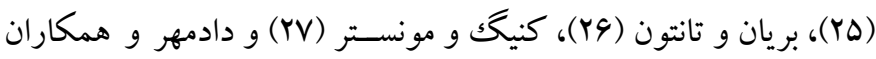
نتايج اين بزوهش را تأييد كردهاند. (YN)

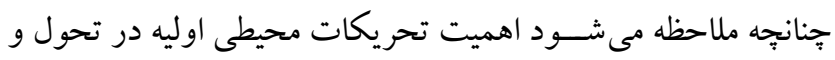

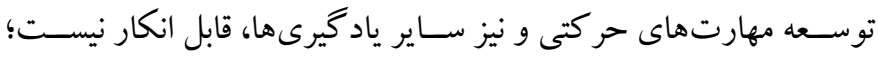

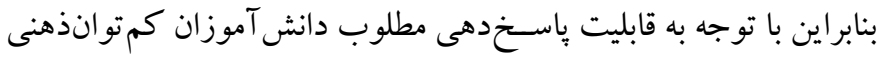

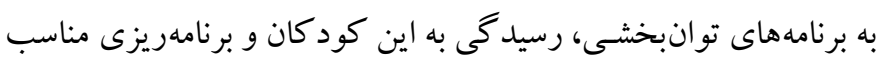

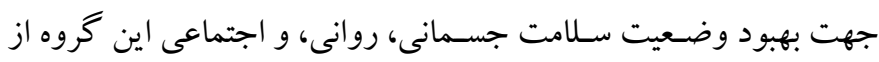

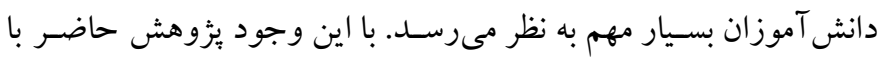

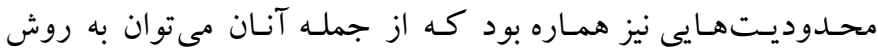

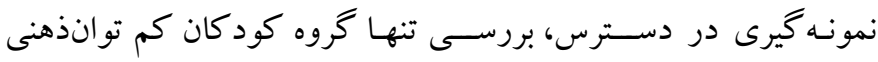

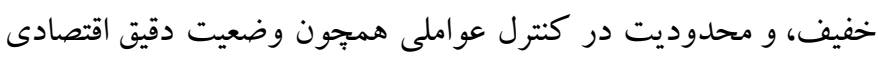

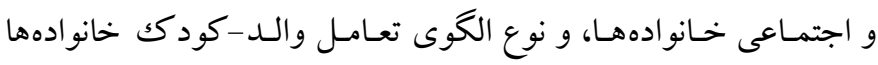
اشـاره كرد. يِيشـنهاد مىشـود در بزوهش هاى آتى اثربخشسى برنامه در 


\section{References}

1. American Psychiatric Association. Diagnostic and statistical manual of mental disorder (DSM-5). Rezaee F, Fakhraee A, Farmand A, Nilofari A, Hashemi Azar J, Shamloo F. (Persian translator). Tehran: Arjmand; 2013. [Persian].

2. Hallahan DP, Kauffman JM, Pullen PC. Exceptional learners: an introduction to special education. 12 edition. Boston: Pearson Education; 2011. [Link]

3. Ahmadi R, Daneshmandi H. The relationship between intelligence and dynamic balance in male students with mental disabilities. Exceptional Education Journal. 2015; 2(130): 31-36. [Persian]. [Link]

4. Dastjerdi M. A Comparative study on the basic motor skills in mentally retarded children. Journal of Exceptional Children. 2003; 2(4): 333-358. [Persian]. [Link]

5. Ashori M, Norouzi G, Jalil-Abkenar SS. The effectiveness of motor therapy on motor skills and bilateral coordination of children with intellectual disability. Iranian Rehabilitation Journal. 2018; 16(4): 331-338. [Link]

6. Srivastava A. Sensory integration strategies for handwriting among autistic children. Academic Journal of Pediatrics \& Neonatology. 2016; 2(1): 555579. [Link]

7. Sadati Firoozabadi S, Abaci SH. The effectiveness of sensory- motor integration on reading problems in students with learning disabilities. Journal of Learning Disabilities. 2018; 8(2): 26-37. [Persian]. [Link]

8. Hadavandkhani F, Bahrami H, Behnia F, Farahbod M, Salehi M. Relationship between Kinesthesia and Handwriting in Students with Mentally Retardation. Journal of Exceptional Children. 2007; 7(1): 97-112. [Persian]. [Link]

9. Dania A, Tyrovola V, Koutsouba M. Proposal for a new method for teaching fundamental motor skills. Procedia - Social and Behavioral Sciences. 2010; 2(2): 4949-4954. [Link]

10. Ghasempoor L, Hosseini FS, Mohammad Zadeh MH. The effect of sensory-motor integration training on gross motor skills of children with severely mental disability. Middle Eastern Journal of Disability Studies. 2015; 4(4): 74-83. [Persian]. [Link]

11. Mailloux Z, Parham LD, Roley SS, Ruzzano L, Schaaf RC. Introduction to the Evaluation in Ayres Sensory Integration ${ }^{\circledR}$ (EASI). Am J Occup Ther. 2018; 72(1): 7201195030p1-7. [Link]

12. Nazari S, Karaminegad R. Methods of accommodation and modification near senses processing disorder in children. Exceptional
Education Journal. 2015; 3(131): 39-46. [Persian]. [Link]

13. Bastian AJ. Understanding sensorimotor adaptation and learning for rehabilitation. Curr Opin Neurol. 2008; 21(6): 628-633. [Link]

14. Sourtji H, Sazmand AH, Karbalaei-Nouri A, Jadidi H. Effect of sensory integration therapy on gross and fine motor skills of 5-7 years old children with down syndrome. Archives of Rehabilitation. 2008; 9(2): 3541. [Persian]. [Link]

15. Mohammadi M, Hadian MR, Olyaie G, Jalili M, Karimi H. The investigation of effects of simultaneous stimulation of exteroception and proprioception on dexterity of 6-7 years old educable children with down's syndrome. Journal of Modern Rehabilitation. 2008; 2(2): 27-32. [Persian]. [Link]

16. Farsi A, Abdoli B, Kaviani M, Kaviani A. The effect of perceptual - motor experience on motor development quotient of fine and gross motor skills in 5-8-month-old infants. Journal of Motor Learning and Movement. 2010; 2(2): 71-84. [Persian]. [Link]

17. Bumin G, Kayihan H. Effectiveness of two different sensory-integration programmes for children with spastic diplegic cerebral palsy. Disabil Rehabil. 2001; 23(9): 394-399. [Link]

18. Baghande H, Homaniyan D, Arab Ameri E. Effect of perceptual-motor training on motor skills of girls with trainable Mental Retardation. Journal of Motor Learning and Movement. 2015; 7(4): 473-490. [Persian]. [Link]

19. Ashori M, Zarghami E, Ghaforian M, Jalil-Abkenar SS. The effect of sensory integration on the attention and motor skills of students with down syndrome. Iranian Rehabilitation Journal. 2018; 16(3): 317-324. [Link]

20. Zeng N, Ayyub M, Sun H, Wen X, Xiang P, Gao Z. Effects of physical activity on motor skills and cognitive development in early childhood: a systematic review. Biomed Res Int. 2017; 2017: 2760716. [Link]

21. Dewey D, Kaplan BJ, Crawford SG, Wilson BN. Developmental coordination disorder: associated problems in attention, learning, and psychosocial adjustment. Hum Mov Sci. 2002; 21(5-6): 905-918. [Link]

22. Salehi H, Zarezadeh M, Salek B. Validity and reliability of the Persian version of motor observation questionnaire for teachers (PMOQ-T). Iranian Journal of Psychiatry and Clinical Psychology. 2012; 18(3): 211-219. [Persian]. [Link]

23. Badami R, Nezakatalhossaini M, Rajab F, Jafari M. 
Validity and reliability of movement assessment battery for children (M-ABC) in 6-year-old children of Isfahan city. Journal of Motor Learning and Movement. 2015; 7(1): 105-122. [Persian]. [Link]

24. Taunton SA. The effects of an integrative universally designed motor skill intervention across general, inclusion, and self-contained early childhood center classrooms [Ph.D. Theses]. [South Carolina, United States]: Department of Physical Education, University of South Carolina; 2018. [Link]

25. Lopes VP, Stodden DF, Rodrigues LP. Effectiveness of physical education to promote motor competence in primary school children. Phys Educ Sport Pedagogy. 2017; 22(6): 589-602. [Link]

26. Brian A, Taunton S. Effectiveness of motor skill intervention varies based on implementation strategy. Phys Educ Sport Pedagogy. 2018; 23(2): 222-233. [Link]

27. König TT, Muensterer OJ. Physical fitness and locomotor skills in children with esophageal atresia-a case control pilot study. Front Pediatr. 2018; 6: 337. [Link]

28. Dadmehr A, Malekpour M, Ghamarani A, Rahimzadeh S. The effective of sensory-motor stimulation in educable mental retarded students with developmental coordination disorder. Exceptional Education. 2014; 2(124): 25-32. [Persian]. [Link]

29. Fink BE, Sensory-motor integration activities. Raghfar M. (Persian translator). First edition. Tehran: Teimurzadeh Publications; 2001. [Persian]. 